\title{
АНГЛОФОНИТЕ НАСЛОВИ ВО ЕДИЦИЈАТА SВЕЗДИ НА СВЕТСКАТА КНИЖЕВНОСТ
}

Румена Бужаровска

Универзитет „Св. Кирил и Методиј“, Скопје

rumena.buzarovska@flf.ukim.edu.mk

Во периодот меѓу 2008 и 2016 година министерствата за култура и образование на Република Македонија се впуштија во остварување грамадни книгоиздателски преведувачки проекти, меѓу кои беше и едицијата од 560

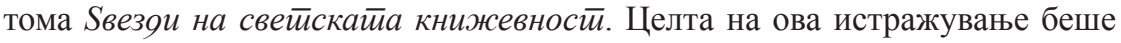
да ги евидентира преведените англофонски наслови во едицијата и да ги анализира основните карактеристики на насловите вклучени во едицијата, а тоа се самиот наслов (преведеното дело или збирка), авторот на насловот, издавачката куќа, преведувачот на насловот, како и авторот на поговорот. Анализата ги зема предвид векот на издавање на насловот/делата, жанрот, литературниот вид, родот на авторот на насловот, преведувачот и авторот на поговорот и потеклото на авторот, а прави и вкрстување меѓу преведувачот и издавачката куќа, преведувачот и жанрот, како и авторот на поговорот и жанрот на насловот.

Клучни зборови: книжевен превод, светска книжевност, англофона книжевност, превод од англиски на македонски, Sвезои на свейскайа книжев-

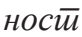




\title{
THE ANLGOPHONE TITLES OF THE STARS OF WORLD LITERATURE EDITION
}

\author{
Rumena Bužarovska \\ Ss. Cyril and Methodius University, Skopje \\ rumena.buzarovska@flf.ukim.edu.mk
}

Between 2008 and 2016, the ministries of culture and education of the Republic of Macedonia launched a massive project involving the translation and publishing of literature. The bulkiest of these projects was the 560 volume titled Stars of World Literature. The aim of my research was to create a database documenting the Anglophone titles included in the edition and to further analyze the basic characteristics of the titles included in the edition, such as the very title itself (the translated individual work or collection of works), the title's author, the publishing house, the translator of the title and the author of the afterword. The analysis takes into account variables such as the century of publication, the genre and sub-genre, the gender of the author, translator and author of afterword, and examines the cross tabulation between translator and publishing house, translator and genre, as well as author of afterword and genre.

Keywords: literary translation, world literature, Anglophone literature, translation from English into Macedonian, Stars of World Literature 


\section{1 Вовед}

Постои една често повторувана мисла во нашата култура, дека македонските преводи не чинат и дека во отсуство на поранешните српско-хрватски преводи, во нашата земја веќе нема што да се чита. Неслучајна е оваа предрасуда кон македонските книжевни преводи: културната доминација на српско-хрватскиот јазик и издаваштво за времето на Југославија, недостигот на книжевно-преведувачка традиција, како и лексикографски изданија и други извори што би можеле да помогнат во процесот на преведување, играа улога во создавањето на оваа слика. Но, постои и уште еден битен фактор за ваквото поимање на состојбата во книжевниот превод, а тоа е недостигот од истражувања и критика од оваа област. Впрочем, недостигот од увид во состојбата на дотогашните книжевни преводи што постоеле, оневозможи создавање стручна дебата, кога Владата на Република Македонија, во периодот од 2008 до 2016 година, распиша тендери и објави преводи на стотици дела во рамките на неколку едиции, со што направи извесен светски преседан во областа на книжевниот превод, со оглед на обемот на опфатени дела. Оттаму, фондот на преведената литература на македонски јазик значително и молскавично се зголеми, оставајќи зад себе низа прашања за преведените дела поврзани со нивниот избор, квалитет, достапност и, конечно - цел.

Со оглед на тоа што во македонската научна мисла единствено истражување кое овозможува увид во преведените дела од светската книжевност на македонски јазик меѓу 1945 и 1990 година е од Анастасија Ѓурчинова и Соња Стојменска-Елзесер, објавено во 1992 година, решив да пристапам кон слично структурирана, но потесна анализа на сите преведени дела од англофоно потекло, и тоа во најмасовната едиција финансирана од Министерството за култура и Министерството за образование и наука на Република Македонија,

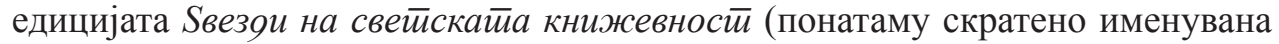
како SCK), која се објавуваше од 2012 до 2016 година и која брои 560 тома. Од научен аспект, ваквото истражување овозможува првичен увид во структурата и во содржината на владиниот проект. Истовремено, тоа претставува прв чекор кон воспоставување рамка за понатамошна анализа не само на книгите објавени во согласност со владиниот проект туку и, општо, на преведената литература по 1990 година. Конечно, едно вакво истражување може да отвори простор за идни истражувања и критики во областа на книжевното преведување. Така, целите на истражувањето се насочени кон евидентирање на преведените англофони наслови на македонски јазик во едицијата SCK, како и анализа на нивните основни карактеристики.

Анализата на карактеристиките подразбира анализа на следниве пет карактеристики на насловите: а) самиот наслов (дело или збирка); б) авторот/ авторката; в) издавачката куќ; г) преведувачот/преведувачката и д) авторот/ авторката на поговорот, со оглед на тоа што секој наслов во едицијата задолжително вклучува и поговор на крајот од книгата. Во ова истражување терминот 
„наслов“ подразбира заокружено дело, кое се раководи под еден наслов, без разлика дали се работи за роман, збирка раскази, драми или есеи, поетска збирка, патопис или, пак, збирка на повеќе дела: антологија или избрани дела на повеќе автори. Од друга страна, ,англофони“ претпоставува дека е насловот изворно напишан на англиски јазик и преведен од англиски на македонски јазик. Во едицијата се присутни и повеќе наслови што се изворно напишани на други јазици, како, на пример, на јапонски или на кинески, а тие се потоа посредно преведени на македонски јазик. Ваквите дела не беа земени предвид во анализата. Конечно, предвид беше земена едицијата Sвезои на светискайа книжевности со оглед на нејзината обемност - 560 дела - како и краткиот рок во кој делата се реализираа - четири години. Потпишани уредници во сите посебни изданија на едицијата се следниве имиња: Митко Маџунков (главен редактор), Луан Старова, Ташко Ширилов, Ефтим Клетников, Драги Михајловски, Венко Андоновски и Ратко Дуев.

Имајќи ја предвид доминантната положба на англо-американската книжевност уште во периодот пред македонската независност или, поточно, до 1990 година - американската и англиската книжевност се застапени со 13,8 \%, односно 11,16 \% (Ѓурчинова и Стојменска-Елзесер 1992: 96) - мојата првична претпоставка беше дека книжевноста со англофоно потекло ќе биде широко застапена во едицијата SCK. Притоа, со оглед на поголемиот историски период во кој се создавала англиската книжевност наспроти американската, очекував дека таa ќе биде процентуално многу позастапена, а и претпоставив дека застапеноста на земји надвор од Северна Америка и Обединетото Кралство, но и Ирска, ќе биде ниска. Уште една појдовна претпоставка е дека ќе има разновидни автори, од различно историско потекло, а и дека значајно ќе доминираат машките автори, со оглед на машката доминација во книжевниот канон. Постоеше и претпоставка дека меѓу преведувачите ќе преовладува женскиот род, а меѓу авторите на поговори - машкиот. Првата претпоставка се темелеше на фактот дека жените во просек заработуваат речиси 80 \% по-

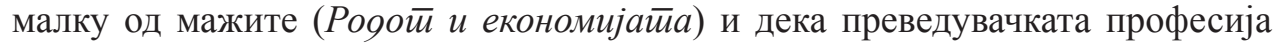
e, општо, ниско платена. Пишувањето на поговор, пак, може да се земе како позиција на поголем авторитет, која, пак, би произлегла од фактот дека жените на пазарот на трудот значително помалку се наоѓаат на раководни позиции (ibid.), како што гледаме, впрочем, и од самиот одбор на едицијата SCK, но и уредниците на сите други владини книгоиздателски изданија од областа на книжевноста. Треба да се земе предвид и фактот дека на Филолошкиот факултет во Скопје дипломираат значително повеќе жени отколку мажи - во 2019 година, од вкупно 249 дипломирани студенти, 214 се жени (Државен завод за статистика, 2020). Последната претпоставка се однесуваше на покажувањето на можна корелација меѓу соработката на извесен преведувач со извесна издавачка куќа.

Со оглед на тоа дека станува збор за првичен преглед во еден навистина обемен проект, со голема количина податоци, се наметнаа поголем број истражувачки прашања: Колкава е застапеноста на англофоните наслови во едицијата SCK? Каква е распределбата меѓу жанровите и меѓу литературните видови? Каква е сликата за застапеноста на насловите во однос на векот од 
кој потекнуваат нивните автори? Каква е родовата застапеност на авторите, преведувачите и авторите на поговорите во едицијата? Кои издавачки куќи се застапени во едицијата и каква е нивната поврзаност со преведувачите на делата? Каква е врската меѓу жанрот и преведувачот на насловот, жанрот и авторот на поговорот?

\section{2 Преглед на литературата}

Евидентирањето, архивирањето и анализата на податоците за преведената литература е воспоставена практика во светот. Можеби најпознат и најзначаен пример е базата на податоци на УНЕСКО Index Translationum (Index Translationum, 2003), која претставува меѓународна библиографија на преводи. Преводите во оваа база на податоци се од земјите членки на УНЕСКО, објавени меѓу 1979 и 2009, и содржат и преводи од други области надвор од книжевноста. Пример, пак, што наликува на анализата на овој труд е проек-

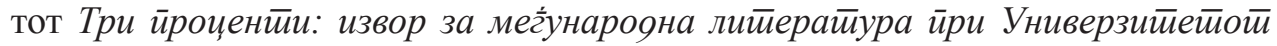
во Рочестере (Three Percent, 2018), кој ги евидентира сите објавени книжевни преводи во САД од 2008 до 2018 година, земајќи ги предвид категориите какви што се насловите на делата, авторите, нивниот род, жанрот, преведувачите, родот на преведувачите, издавачката куќа и годината на издавање.

Како што веќе споменав во воведот, единствено истражување кое нуди потемелен увид во светската книжевност преведена на македонски јазик е на Анастасија Ѓ урчинова и Соња Стојменска-Елзесер во рамките на проектот „Македонско-странски книжевни врски“ при Институтот за македонска литература (Ѓурчинова и Стојменска-Елзесер 1992: 94). Во истражувањето, кое го опфаќа периодот од 1945 до 1990 година, авторките вклучиле автори и дела од 14 национални книжевности (руската, француската, американската, англиската, германската, италијанската, шпанската, јужноамериканската, романската, полската, чешкословачката, турската, грчката и класичната), сметајќи дека тие се најприсутни и најзначајни за развојот на македонската книжевност. Користејќи повеќе каталози, но и магистерски и докторски трудови, како и објавени библиографии, тие направиле статистичка обработка на вкупно 950 библиографски единици објавени како засебни дела и тоа на три нивоа:

a) според бројната и процентуалната застапеност;

б) според динамиката на преведувањето во одделни периоди (и децении) за најзастапените национални литератури;

в) според родово-жанровската застапеност.

Во рамките на бројната и процентуалната застапеност, истражувачките анализирале кои книжевности се најпреведувани: на прво место, руската - со 289 единици; на второ, француската - со 158; на трето, американската - со 131; на четврто, англиската - со 106 единици. Кои автори се најприсутни во рамките на националните книжевности: Максим Горки со 24 единици, Жил Верн со 15 единици, Џек Лондон со 15 единици, Вилијам Шекспир со 16 единици. Но, и кои преведувачи се најплодни: Цветко Мартиновски од руски со 22 единици, Влада Урошевиќ од француски со 12 единици, Свето Серафимов 
за американската книжевност со 19 единици, а и од англиската со 18 единици (Ѓ урчинова и Стојменска-Елзесер 1992). При анализата на динамиката на преведување според одредени децении, авторките посочиле во текот на кои периоди извесна книжевност бележи пад, раст или, пак, стагнација во бројот на преведени единици, па така се забележува, на пример, дека руската книжевност бележи истакнат раст во текот на 1960-тите години, додека американската книжевност покажува постојан пораст, со што најголем број преведени единици (48) се произведуваат во текот на 1980-тите години. Конечно, родово-жанровската застапеност бележи најголема застапеност на прозата со 78 \%, 17,16 \% на поезијата и само 4,84 \% на драмата. Жанровската застапеност е потоа претставена процентуално за секоја од четиринаесетте анализирани национални книжевности одделно.

Уште еден обемен труд кој се стреми да даде хронолошки осврт на теоријата и практиката на преведувањето во Република Македонија, со акцент на поезијата, застанувајќк токму кај владините проекти за преведување како SCK, e

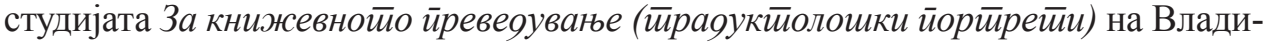
мир Цветкоски (Цветкоски 2017). Освен што трудот содржи книжевно-преведувачки портрети на шест значајни македонски преведувачи (Михаил Д. Петрушевски, Венко Марковски, Блаже Конески, Георги Сталев, Богомил Гу узел и Драги Михајловски), тој содржи и осврт кон научните придонеси од полето на книжевниот превод остварени за време на Меѓународните средби на книжевните преведувачи во Тетово, средби што се одржуваат од 1972 година до денес (ibid., 149) во организација на Друштвото на книжевни преведувачи во Македонија. Цветкоски ги издвојува значајните реферати од македонски учесници на средбите, со оглед на тоа што дел од зборниците со трудовите се недостапни, а и се јавува прекин во континуитетот на објавувањето на зборниците. Токму затоа прегледот на реферати што го нуди Цветкоски е посебно корисен, имајќи ги предвид тешкотиите за пронаоѓње на овие зборници поради неодговорното архивирање. Понатаму, Цветкоски нуди значаен преглед на учебниците, магистерските трудови и докторските дисертации објавени од 1973 до 2013 година. Меѓу трудовите што ги наведува тој, а кои вршат пресек и критика на дела од англофона провениенција, е трудот на Александрина Илиева Анг̄лискиой ро-

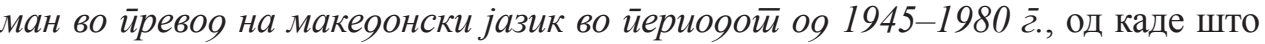
дознаваме дека во периодот 1945-1980 година „биле преведени и објавени 28 романи од англиска книжевност од 21 автор“ (ibid., 178). Уште еден труд што може да се поврзе со нашето истражување, а на кој се осврнува Цветкоски, е

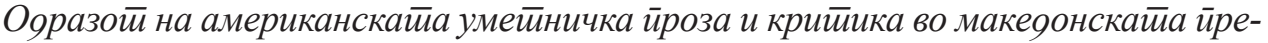
вояна и критиччко-есеистиччка книжевности од Виолета Христовска, каде што дознаваме дека во периодот од 1945 до 1982 година биле објавени 66 преводи на американски романи (Цветкоски 2017: 179).

Придонес кон теоријата и практиката на книжевното преведување дава и списанието Кулйурен животи, во кое редовно се објавуваат преведувачки рецензии или, пак, статии од областа на теоријата на книжевното преведување, но голем дел од овие статии не се архивирани во Националната и универзитетска библиотека (НУБ) и недостасуваат во датабазата на COBISS.MK. Ова го воочив кога забележав дека мојот текст за преводите на Ловец во 'ржӣа од 
Селинџер „Игри со ловците во 'ржта“ (Бужаровска 2015) воопшто не е заведен во системот, а таков пример најдов и при текстот на Звонко Танески „Критиката на книжевните преводи: неопходни фактори и простор за вреднување (македонско-словачки негативни искуства)“ (Танески 2013), како и „Јазикот, литературата и преводот“ од Огнена Никуљски (Никуљски 2013). Од друга страна, некои трудови посветени на книжевноста и преведувањето и објавени

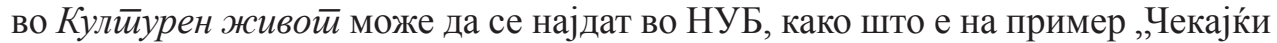
го вистинскиот збор“ (Кошка-Хот 2012). Ваквиот проблем при неодговорното каталогизирање и наложува потреба од алтернативно пронаоѓање и архивирање на овие текстови.

Во последно време електронското списание за култура Окно (okno.mk) објавува значајни рецензии и дискусии од областа на книжевното преведување. Се издвојува текстот на Калина Малеска за проблемите при објавувањето на нејзиниот неавторизиран превод на Хаклбери Фин и тоа во рамките на проектот SCK (Малеска 2014), а од 2019 година дипломците по англиски јазик и книжевност при Катедрата за англиски јазик и книжевност при Филолошкиот факултет „Блаже Конески“ објавуваат свои рецензии за преводи од англофоно потекло, како, на пример, за Чарлс Буковски (Рашко 2019), Џон Штајнбек (Ивановска 2019), Вилијам Шекспир (Станојевиќ 2019), Алис Вокер (Димитровска 2020), Вирџинија Вулф (Спасиќ 2020) и Џејмс Џојс (Андоновска 2020), со што придонесуваат кон создавање традиција на конструктивна критика во и онака штуриот пејзаж на македонските рецензии од областа и на преведувањето и на книжевноста.

\section{3 Методологија на истражувањето}

Со оглед на природата на анализираните податоци, се работи за квантитативно истражување, со примена на постапки што спаѓаат во таканаречената експлоративна анализа на податоци (или: Exploratory Data Analysis).

\section{1 Дизајн на истражувањето}

\subsection{1 Популација}

Едицијата SCK може да се прегледа во Кайалог̄ой на кайийални книг̄оизяа-

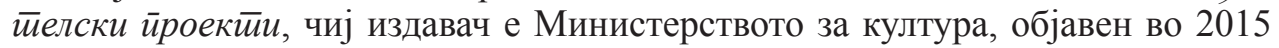
година. Воведниот текст на ова издание наведува дека тоа „опфаќа 560 дела“ (К'улавковска 2015: 3), но при преглед на едицијата (стр. 81-155) веднаш настанува проблем при обидот за дефинирање на поимот gело. Имено, уредниците на едицијата под овој термин не подразбирале едно заокружено книжевно дело од почеток докрај, како, на пример, роман, збирка раскази или поетска збирка, или, пак, роман со сите свои томови во една единица, туку секој том од едицијата го нумерирале како засебна единица. Проблемот се усложнува уште повеќе кога ќе се земе предвид дека во едицијата се појавуваат збирки на пократки книжевни форми (раскази, поезија, есеи, драми, новели и приказни) групирани во една или повеќе книги, и тоа како антологии на неколку автори или неколку избрани дела од еден автор што можат да припаѓаат на различни 
жанрови (на пример, роман и есеј, каков што е случајот со изданието чиј автор е Едгар Алан По). Покрај романите и збирките, едицијата содржи и документаристичка проза и биографии, од кои некои се во повеќе томови. Оттаму, бројот 560 никако не може да биде вистинскиот број на преведени книжевни дела во оваа едиција. Имајќи го предвид овој недостаток при составувањето и попишувањето на едицијата, во ова истражување најпрво беше одлучено да се евидентираат единиците со англофона книжевност: беа добиени 159 единици (или 28,39 \% од 560-те единици на едицијата) (графички приказ 1). Понатаму, томовите на еден роман беа здружени во една единица (внес), со што беше дојдено до финалниот број од 146 поединечни единици. Имајќи предвид дека во натамошната разработка се работеше со сите 146 внесови (односно не беше направено семплирање), овој број ја дефинираше йойлацијай $а$ на истражувањето. Овие 146 внесови беа наречени наслови, под што се подразбира наслов на дело и наслов на збирка, со што тој термин се користи во натамошната анализа.

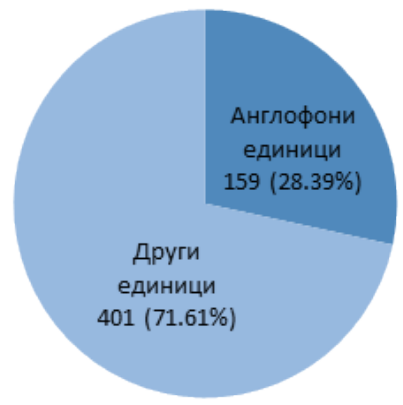

Графички приказ 1. Англофоните наспроти другите единици

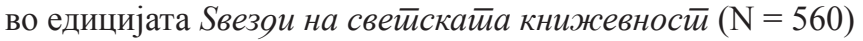

\subsection{2 Истражувачки инструмент}

Податоците за 146-те наслови беа собрани со помош на истражувачки прашалник составен од 28 полиња: реден број; број според едицијата SCK; наслов на делото/збирката; наслови во збирка; оригинален наслов; томови на едно дело; година на првото издание; век на првото издание; жанровска класификација; литературен вид; други специфики; вид граѓa (COBISS.MK); автор(ка); број на автор(к)и; род (автор/ка); потекло; преведувач(ка); број на преведувач(к)и; род (преведувач/ка); наслов на поговор; автор(ка) на поговор; број на автор(к) и на поговор; род (автор/ка на поговор); издавачка куќа; година на издавање; траен линк COBISS.MK (тврд повез); траен линк COBISS.MK (мек повез) и забелешки.

\subsection{3 Истражувачка процедура}

Целата процедура на истражувањето, од подготовката, преку поставувањето на предметот и конципирањето на методологијата, до собирањето на пода- 
тоците, нивната проверка и анализата, се одвиваше од јануари до септември 2020 година. Во процесот на собирање на податоците беше користен Кайало-

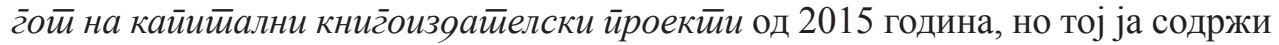
нумерацијата само на 410 книги во едицијата, кои биле дотогаш издадени. За другите 150 книги е наведено дека се во завршна фаза и за нив е изоставена нумерацијата. За да се дополнат податоците, во следната фаза беше користен електронскиот каталог COBISS.MK. Во него беше направено (изборно) пребарување според наслов и клучни зборови. Терминот што беше пребаруван

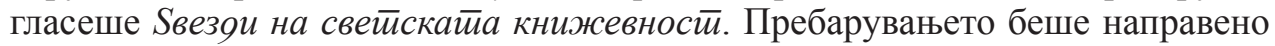
од 1 до 10 септември 2020 година. Под Наслов беа добиени 365 погодоци, а под клучни зборови - 742. Големиот број погодоци се должи на фактот што одредени наслови се повторуваа: некои се повеќепати издадени (како дел од едицијата), постојат печатени верзии во тврд и во мек повез, а томовите некогаш се наведени како засебни книги (секоја со различен ISBN), но не во сите

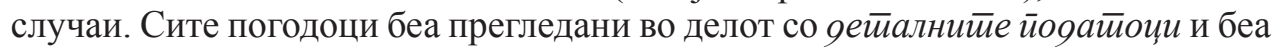
селектирани само оние наслови кај кои беше запишано дека станува збор за превод (и/или препев) од англиски јазик. Во едицијата се појавуваат наслови со посреден превод од англиски јазик, но имајќи предвид дека посредниот превод е засебен истражувачки проблем, овие наслови не беа вклучени во истражувањето. Пребарувањето понекогаш беше отежнато поради грешки во презимињата на авторите (на пр. Т.С. Елиот еднаш е Томас Стернс Елиот, другпат е Томас Стернз Елиот). Во каталогот COBISS.MK забележавме дека некаде изостануваа редните броеви на книгите, кои треба да бидат поставени

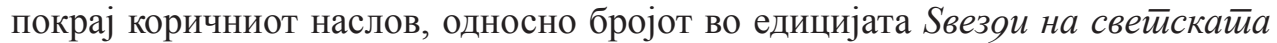

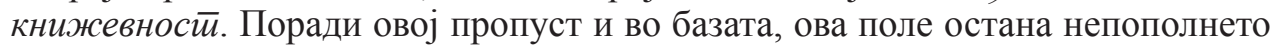
за 15 наслови.

Битно е да се напомене дека за едицијата постои официјален сајт, но во него се евидентирани само 46 книги од оваа едиција (Кайалог̄ на книг̄u, 3334). Покрај ова, делот за пребарување - најои книг̄a, не дава никакви резултати. Иако редакторот Митко Маџунков во текстот во кој ја објаснува идејата зад едицијата SCK вели дека „кон едицијата ќе биде придодаден списокот на книгите што се составен дел од проектната програма, со сите нужни податоци, а што е поважно, Редакцијата ќе изработи одделна студија за создавањето на 'Sвездите на светската книжевност', за својата концепција и воопшто за реализацијата на целиот проект, како и за јазичната проблематика што се наметна во текот на таа реализација““ (Маџунков 2012: 4), такво нешто никогаш не се случи.

\section{2 База на податоци и техники на анализа}

Истражувачкиот прашалник беше преведен во база на податоци и, врз основа на податоците внесени во базата, беше направена квантитативната анализа. Базата и квантитативната обработка, која вклучува фреквенциски дистрибу-

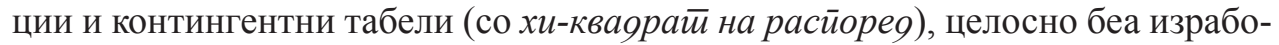
тени во Microsoft Excel. 


\section{3 Методолошки ограничувања}

Начинот на кој се заведени податоците за едицијата во Кайалог̄ой на кайи-

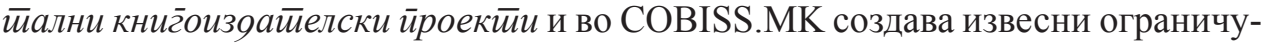
вања при евидентирањето на насловите. Понатаму, поради фактот дека едицијата е создадена од наслови во кои се вклучени повеќе автори, како и збирки во кои има повеќе жанровски одредници, а и дека во извесни наслови се јавуваат повеќе преведувачи, тешко е да се создаде концизна слика за тоа кои автори се најиздавани и кои преведувачи се најзастапени, со оглед на тоа што некои од преведувачите, на пример, се јавуваат со помали преведени парчиња во рамките на извесни антологии. Исто така, во базата не е евидентирана големината на преведените дела, со што не се дава јасна слика за ангажираноста на одреден преведувач.

\section{4 Резултати од истражувањето 4.1 Наслов}

Следуваат дистрибуции на 146 наслови според векот во кој се создадени англофоните дела, нивната жанровска класификација и нивниот потесен литературен вид.

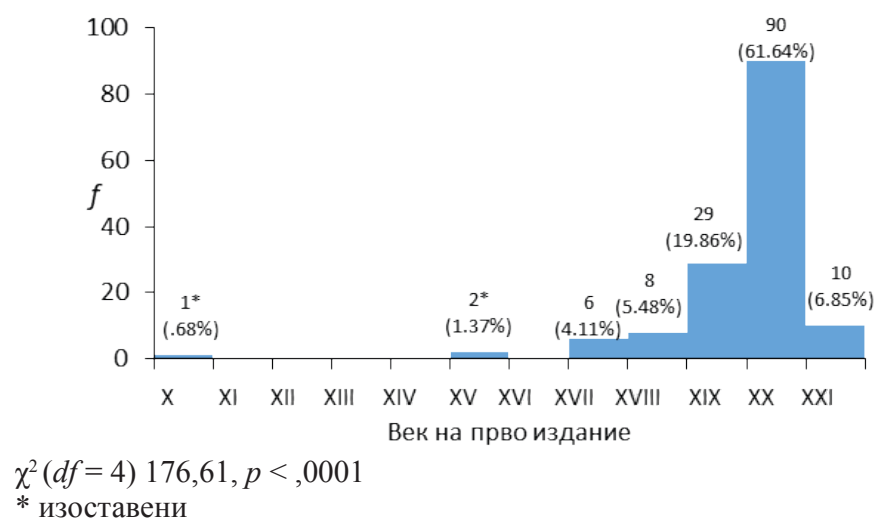

Графички приказ 2. Англофони наслови според векот во кој биле создадени $(\mathrm{N}=146)$

Резултатите од оваа анализа (графички приказ 2) покажуваат до која мера доминира книжевноста од 20 век во избраниот светски книжевен канон утврден од уредниците на SCK, што до извесен степен изненадува. Така, дури $61,64 \%$ од сите наслови потекнуваат од 20 век, додека на второ место со далеку помала застапеност - 19,86 \% - се делата од 19 век, по што следуваат насловите од 21 век, со $6,85 \%$. Ова не се совпаѓa сосема со тврдењето на Маџунков дека „претежниот број на застапени автори се родени пред 1910 година (односно од нивното раѓање има поминато повеќе од сто години), што е доволна дистанца за да се создаде конечен вредносен суд“ (Маџунков 2012: 
3). И самиот тој вели дека „некои автори се премногу млади за еден ваков избор“ (ibid.), имајќи ја предвид замислата дека едицијата „претставува избор на она што веќе станало класика“ (ibid.), но нејасно е зошто младите автори ce, сепак, вклучени во едицијата. Се споменуваат извесни „странски експерти“, но не е јасно кои биле тие и каква била нивната улога во создавањето на едицијата.

Распределбата, пак, на наслови според трите доминантни жанрови на проза, поезија и драма, покажува дека прозата е далеку најзастапена во едицијата, co $74,66 \%$ (графички приказ 3). Очекувано, поезијата е на второ место со 14,38 \%, додека драмските дела се најмалку застапени, со 9,59 \%.

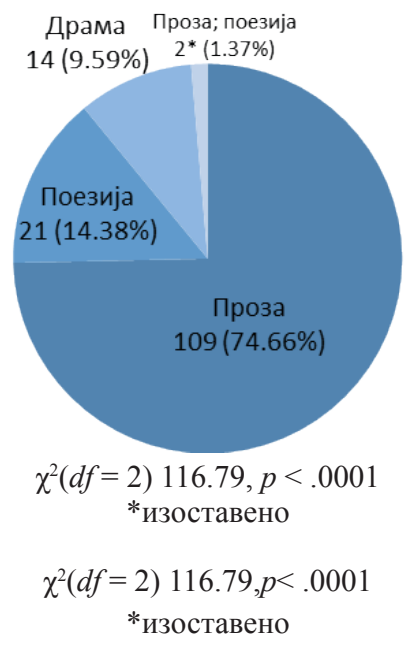

Графички приказ 3. Жанровска класификација $(\mathrm{N}=146)$

Потесниот литературен вид во овој случај, главно, се однесува на различните видови проза што се јавуваат во англофоните изданија на едицијата. Освен романот, расказот и новелата, присутни се есејот, биографијата, документаристичката проза, приказната и митографијата. Од поетскиот жанр се јавува епот, како и хибридниот вид поезија во проза. Очекувано, најзастапениот литературен вид во едицијата SCK е романот, со 57,53 \%, додека зад него со $12,33 \%$ е поезијата. Интересно е што расказот е на четврто место, со оглед на тоа што едицијата содржи само шест збирки раскази, со што пред таа форма предничат и есејот и драмата (табела 1). Оваа распределба покажува и како одредени наслови комбинираат различни литературни видови, каков што е примерот со Радјард Киплинг и насловот Книга з за иунг̄ла$\bar{u} a ;$ Поезија - приказна и поезија или, пак, изборот раскази и песни од Едгар Алан По (Поезија; Раскази). 
Табела 1. Распределба на насловите според литературниот вид

\begin{tabular}{|c|c|c|}
\hline Литературен вид & $f$ & $\%$ \\
\hline Роман & 84 & $57,53 \%$ \\
\hline Поезија & 18 & $12,33 \%$ \\
\hline Драма & 14 & $9,59 \%$ \\
\hline Ecej & 7 & $4,79 \%$ \\
\hline Расказ & 6 & $4,11 \%$ \\
\hline Документаристичка проза & $4 *$ & $2,74 \%$ \\
\hline Еп & $2 \times 2 *$ & $1,37 \%$ \\
\hline \multicolumn{3}{|l|}{ Новела } \\
\hline Роман; есеј & $9 \times 1 *$ &, $68 \%$ \\
\hline \multicolumn{3}{|l|}{ Приказна; роман } \\
\hline \multicolumn{3}{|l|}{ Приказна; поезија } \\
\hline \multicolumn{3}{|l|}{ Драма; есеј } \\
\hline \multicolumn{3}{|l|}{ Митографија } \\
\hline \multicolumn{3}{|l|}{ Поезија во проза } \\
\hline \multicolumn{3}{|l|}{ Биографија } \\
\hline \multicolumn{3}{|l|}{ Поезија; расказ } \\
\hline \multicolumn{3}{|l|}{ Новела; расказ } \\
\hline Вкупно & 146 & $100 \%$ \\
\hline
\end{tabular}

\section{2 Автор(ка)}

Вкупниот број категории што се појавуваат во полето авйор(ка) е 121. Сепак, треба да се има предвид дека во нив има четири наслови на збирки и антологии со творештво на повеќе автори. Така на пример, Џејмс Џојс, Томас Стернз Елиот, Вирџинија Вулф и Вилијам Шекспир се застапени со најголем број наслови (три). Седумнаесетте автори потпишани на два наслова се: Даниел Дефо, Роберт Луис Стивенсон, Едгар Алан По, Вилијам Батлер Јејтс, Ернест Хемингвеј, Џозеф Конрад, Езра Паунд, Џон Максвел Куци, Лоренс Стерн, Д.Х. Лоренс, Вилијам Фокнер, Чарлс Дикенс, Хенри Џејмс, Вистан Хју Одн, Џејн Остин, Владимир Набоков и Џон Штајнбек. Имајќи ги предвид збирките, без разлика што ги сметаме за една целина, можеме да евидентираме уште четворица автори чие творештво се појавува во два наслова: Џорџ Гордон Бајрон и Перси Биш Шели се јавуваат како автори на цел наслов и како дел од збирка. Понатаму, творештвото на Вилијам Бароуз е застапено со роман и како дел од антологија, а поезијата на Ален Гинзберг е вклучена во две антологии. Инаку, може да се изведе следната дистрибуција на автори според бројот на наслови, во која над две третини од авторите се појавуваат со по еден наслов:

Табела 2. Застапеност на автор(к)ите со наслови

\begin{tabular}{lrr}
\hline Број на наслови & $f$ на автор(к)и & \multicolumn{1}{c}{$\%$} \\
\hline Со еден наслов & 100 & $68,49 \%$ \\
Со два наслова & 17 & $23,29 \%$ \\
Со три наслови & 4 & $8,22 \%$ \\
\hline Вкупно & 121 & $100 \%$ \\
\hline
\end{tabular}


Во следната дистрибуција на автори (графички приказ 4) е прикажана родовата распределба меѓу авторите, што не е изненадувачка. Со оглед на тоа што општоприфатениот канон во светската книжевност е машки, а и тоа што меѓу уредниците на едицијата нема ниту една жена, и овде доминираат машките автори со 85,62 \%, додека авторките се застапени со само 13,01\%. Во еден случај имаме дело од анонимен автор (Беовулф), како и збирка со три автори и една авторка (избор поезија во која е застапена и Силвија Плат, покрај тројца други машки автори од англо-американско потекло - Карл Сандберг, Алан Гинзберг и Тед Хјуз). Сепак, имајќи ја предвид широката застапеност на современата книжевност во едицијата, во која авторките се многу поприсутни отколку, да речеме, во 19 век, разочарува - но, и не изненадува - одлуката на уредниците да вбројат толку мал избор наслови од авторки. За ставот на комисијата кон авторките што припаѓаат во светскиот канон многу зборува тврдењето на Маџунков дека во едицијата, сепак, се вклучени дела што „просто не припаѓаат на самиот врв на светската книжевност“, при што како пример ја наведува Мери Шели (Маџунков 2012: 3).

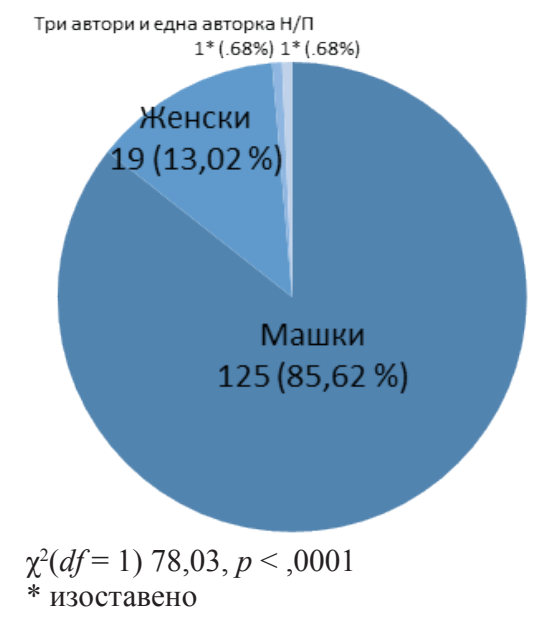

Графички приказ 4. Англофони наслови според

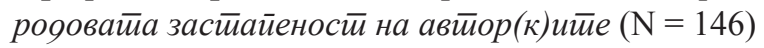

Насловите се понатаму распределени според земјата на потекло на авторот. Треба да се земе предвид дека земјите на потекло се дефинирани според денешните нивни називи. Па, така, иако во времето кога бил створен Беовулф не постоело Обединетото Кралство на Велика Британија и Северна Ирска, делото е условно ставено во рамките на таа книжевност, како извесна културно-географска определба. Насловите со автор од Ирска се ставени во посебна категорија, и покрај географската близина и користењето на истиот јазик, поради политичките разлики, кои често ја дефинираат ирската книжевност. Во голем број случаи авторите припаѓаат на две географски традиции или, пак, на две книжевности - таков е случајот со авторот Александар Хемон, кој по потекло е од Босна и Херцеговина, но живее во САД и пишува 
на англиски јазик или, пак, Владимир Набоков и Јосиф Бродски, знаменити руско-американски автори. Слична е и ситуацијата со англо-американските автори како Т.С. Елиот и Езра Паунд, додека во едицијата се појавуваат и мал број изданија од автори што потекнуваат од поранешни британски колонии, како Индија (на пример, Киран Десаи) и Јужна Африка (Џ.М. Куци). Сепак, очигледна е доминантноста на она што го нарекуваме англиска или британска книжевност, која е застапена со 44,52 \%.

Табела 3. Англофони наслови според йоиееклойо на авйорийе

\begin{tabular}{lrr}
\hline Земја & $F$ & \multicolumn{1}{c}{$\%$} \\
\hline Обединето Кралство на Велика Британија и & 65 & $44,52 \%$ \\
Северна Ирска & 48 & $32,88 \%$ \\
Соединети Американски Држави & 10 & $6,85 \%$ \\
Ирска & 7 & $4,79 \%$ \\
САД и Обединето Кралство & 3 & $2,05 \%$ \\
САД и Русија & 3 х 2 & $1,37 \%$ \\
Јужна Африка & & \\
Нигерија & 7 x 1 & \multirow{2}{*}{, $68 \%$} \\
Австралија & & \\
Канада & & \\
Обединето Кралство и Јужна Африка & & \\
Обединето Кралство и Ирска & & \\
САД; САД; Обединето Кралство; САД & & \\
САДи Либан & & $100 \%$ \\
Индија & 146 \\
САД и Канада &
\end{tabular}

\section{3 Издаваштво}

Податоците поврзани со издавањето на насловите се претставени во контингентна табела, со додадена процентуална застапеност на издавачките куќи (по вертикала) и годините на издавање (по хоризонтала). Треба да се земе предвид дека издавачките куќи се наоѓаат во различни комбинации со други издавачки куќи, по што произлегува дека конечниот обем на работа на извесна издавачка куќа во однос на изданието на англофоните дела е немерлив (табела 4). 
Табела 4. Англофони наслови според изоавачка куќа и г̃омина на изоавање

\begin{tabular}{|c|c|c|c|c|c|c|}
\hline \multirow{2}{*}{ Издавачка куќа } & \multicolumn{5}{|c|}{ Година на издавање } & \multirow{2}{*}{ Вкупно } \\
\hline & 2012 & 2013 & 2014 & 2015 & 2016 & \\
\hline $\begin{array}{l}\text { Конгресен сервисен центар, } \\
\text { Макавеј, Микена }\end{array}$ & 18 & 19 & 12 & 1 & & $\begin{array}{r}50 \\
34,25 \%\end{array}$ \\
\hline Магор & 17 & 10 & 12 & 5 & 2 & -36 \\
\hline $\begin{array}{l}\text { Конгресен сервисен центар, } \\
\text { Макавеј }\end{array}$ & & 9 & 6 & 2 & & $\begin{array}{rl}17,51 & 0 \\
11 & 04 \%\end{array}$ \\
\hline Арс Ламина - публикации & & 4 & 9 & 2 & & $\begin{array}{r}15 \\
10,27 \%\end{array}$ \\
\hline Три, Арс Ламина - публикации & & 6 & 2 & & & $5,48 \%$ \\
\hline Ад Вербум & & & & 3 & 1 & $2,74 \%$ \\
\hline Три & 2 & & & & & $\begin{array}{r}2 * \\
1,37 \%\end{array}$ \\
\hline Арс студио, Нампрес & & & & 2 & & $1,37 \%$ \\
\hline Нампрес & & & & & 1 &, $68 \%$ \\
\hline Арс студио & & & & & 1 & $68 \%$ \\
\hline Вкупно & $\begin{array}{r}37 \\
25.34 \% \\
\end{array}$ & $\begin{array}{r}48 \\
32,88 \% \\
\end{array}$ & $\begin{array}{r}41 \\
28,08 \% \\
\end{array}$ & $\begin{array}{r}15 \\
10,27 \%\end{array}$ & $\begin{array}{r}5 \\
3,42 \% \\
\end{array}$ & $\begin{array}{r}146 \\
100 \% \\
\end{array}$ \\
\hline
\end{tabular}

\section{4 Преведувач(ка)}

За разлика од родовата застапеност на авторите на насловите, очекувано беше, со оглед на ниската платеност и непрестижноста на професијата, како и доминантноста на женскиот наспрема машкиот род при студиите на Филолошкиот факултет, дека преведувачките ќе доминираат над преведувачите. Имено, се покажа дека $67,81 \%$ од насловите се преведени од жени, а само $28,08 \%$ од мажи. Во шест наслова се појавија повеќе преведувачи во кои има застапеност и на мажи и на жени (графички приказ 5).

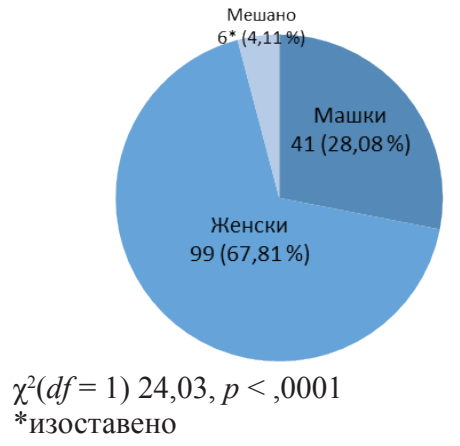

Графички приказ 5. Англофонски наслови според

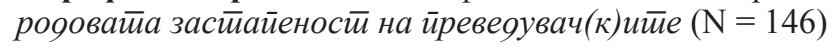


За да се добие подетален преглед на тоа кои преведувачи со кои издавачки куќи најмногу соработувале во едицијата SCK, дистрибуцијата за преведувач(ка) е вкрстиена најпрво со изоавачка куќа и добиените резултати се поставени во контингентна табела. Така, на пример, се забележува дека извесни преведувачи соработуваат со извесни издавачки куќи, како Марија Џонс и Зорица Теофилова со Магор. На крајот се дава увид и во вкупниот број преведени дела од еден преведувач или (кога станува збор за збирки на дела) повеќе преведувачи (такви ситуации има вкупно 16). Така, на пример, драмите на Харолд Пинтер имаат најголем број преведувачи - четворица. Во контингентната табела го има на увид и вкупниот број наслови според издавачките куќи (додаток 1). Следуваат податоците за првите дваесет преведувачи според квантитетот на преведени наслови во едицијата (табела 5).

Табела 5. Англофони наслови според ирревеgувач(ка) и изяавачка куќа. Збирните фреквенции се рангирани. Преведувач(к)ите што се појавуваат и во наслови со повеќе преведувач(к)и се болдирани и до нив е наведен бројот на дополнителни наслови. Наведени се првите 20 полиња

\begin{tabular}{|c|c|c|c|c|c|c|c|c|c|c|c|}
\hline \multirow[b]{2}{*}{ Преведувач(ка) } & \multicolumn{10}{|c|}{ Издавачка куќа } & \multirow[b]{2}{*}{ 跑 } \\
\hline & 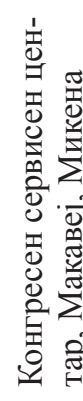 & $\frac{0}{2}$ & 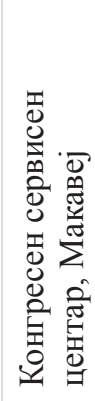 & 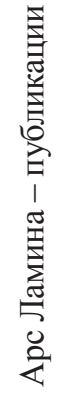 & 蒠 & 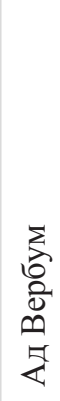 & ڤี & 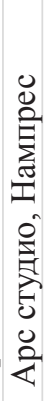 & : & 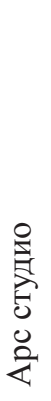 & \\
\hline Џонс, Марија (+4) & & 10 & & & & & & & & & 10 \\
\hline Теофилова, Зорица & & 8 & & 1 & & 1 & & & & & 10 \\
\hline Михајловски, Драги (+1) & & & 8 & & & & & & & & 8 \\
\hline Анчевски, Зоран (+2) & 2 & 6 & & & & & & & & & 8 \\
\hline Илковска, Ивана & & & & 4 & & & & 2 & & 1 & 7 \\
\hline Балоска, Ивана & 3 & & 3 & & & & & & & & 6 \\
\hline Гароска-Ацеска, Катица (+2) & 4 & & & & & & 1 & & & & 5 \\
\hline Г̈узел, Богомил (+2) & 2 & & & & 3 & & & & & & 5 \\
\hline Тодорова, Марија & 4 & & & & & & & & & & 4 \\
\hline Цветковски, Владимир & 2 & & 1 & & 1 & & & & & & 4 \\
\hline Кошка-Хот, Рајна (+3) & 2 & 2 & & & & & & & & & 4 \\
\hline Утковска, Јасмина & 1 & & & 3 & & & & & & & 4 \\
\hline Пемова, Василка & 3 & & & & & & & & & & 3 \\
\hline Мицкоски, Николче & 2 & & 1 & & & & & & & & 3 \\
\hline $\begin{array}{l}\text { Богеска-Анчевска, Благородна } \\
(+1)\end{array}$ & 3 & & & & & & & & & & 3 \\
\hline Малеска, Калина & 2 & & & & 1 & & & & & & 3 \\
\hline Јанева, Калина (+1) & 2 & & 1 & & & & & & & & 3 \\
\hline Чаповска, Вера & 3 & & & & & & & & & & 3 \\
\hline Бакалинова-Атанасова, Зора & 2 & & & & & & & & & & 2 \\
\hline Буразер Китановска, Мирјана & 1 & & & & 1 & & & & & & 2 \\
\hline
\end{tabular}


Табелата 6 дава увид во преведените англофони наслови вкрстувајќи ги дистрибуциите за ирревеяувач(ка) и жанр, со што се наведени само првите 11 полиња како најрелевантни. Вкрстувајќи го преведувачот и жанрот, се стекнува увид во преведувачката специјалност на одредени преведувачи веќе етаблирани во нашата култура. Така, на пример, анализата покажува дека во едицијата SCK најзастапени преведувачи на поезија се Драги Михајловски, Богомил Ѓ узел и Зоран Анчевски, додека најзастапена преведувачка на драмски текстови е Рајна Кошка-Хот.

Табела 6. Англофони наслови според ирревеgувач(ка) и жанр. Збирните фреквенции се рангирани. Преведувач(к)ите што се појавуваат и во наслови со повеќе преведувач(к)и се болдирани и до нив е наведен бројот на дополнителни наслови. Во табелата се наведени само првите 11 полиња

\begin{tabular}{|c|c|c|c|c|c|}
\hline \multirow[b]{2}{*}{ Преведувач(ка) } & \multicolumn{4}{|c|}{$\begin{array}{c}\text { Жанровска } \\
\text { класификација }\end{array}$} & \multirow[b]{2}{*}{ 胥 } \\
\hline & 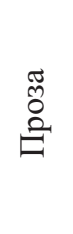 & 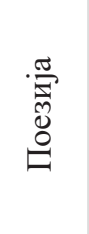 & $\begin{array}{l}\sum_{\tilde{E}}^{\tilde{Z}} \\
\stackrel{2}{\tilde{Z}}\end{array}$ & 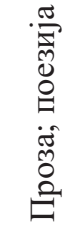 & \\
\hline Џонс, Марија (+4) & 10 & & & & 10 \\
\hline Теофилова, Зорица & $\underline{9}$ & 1 & & & 10 \\
\hline Михајловски, Драги (+1) & & 6 & 2 & & 8 \\
\hline Анчевски, Зоран $(+2)$ & $\underline{4}$ & 3 & 1 & & 8 \\
\hline Илковска, Ивана & 6 & & 1 & & 7 \\
\hline Балоска, Ивана & 6 & & & & 6 \\
\hline Гароска-Ацеска, Катица (+2) & 5 & & & & 5 \\
\hline Г̈узел, Богомил (+2) & & 4 & 1 & & 5 \\
\hline Тодорова, Марија & $\underline{4}$ & & & & 4 \\
\hline Цветковски, Владимир & $\underline{4}$ & & & & 4 \\
\hline Кошка-Хот, Рајна (+3) & & & 4 & & 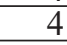 \\
\hline
\end{tabular}

\section{5 Автор(ка) на поговор}

Сите наслови на едицијата SCK задолжително содржат краток поговор за делото, збирката или антологијата претставена во насловот. Само во два случаи поговор не се јавува: кај Ловец во 'ржта од Џ.Д. Селинџер и Децайа на йолноќй $а$ од Салман Ружди, и тоа поради правила наложени од авторите при отстапувањето на авторските права. Сите поговори во едицијата се напишани од еден автор, освен кај еден наслов од Оскар Вајлд, каде што се појавуваат две имиња: Александар Прокопиев пишува за Среќкиот̄ йрини, додека Елизабета Шелева за Сликайа на Доријан Греј, меѓутоа станува збор за поврзан опус со два каталошки броја, кој секаде се води како една целина.

Графичкиот приказ 6 ја прикажува родовата распределба меѓу авторите на поговори: 


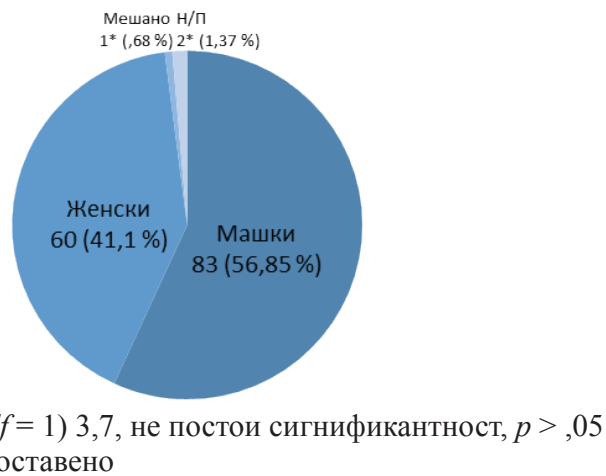

Графички приказ 6. Родова застапеност на автор(к)ите на поговор $(\mathrm{N}=146)$

Интересно е што при оваа застапеност повторно имаме доминација на машките автори, што може да се доведе во врска, како што веќе беше наведено во воведот, со нивните раководни позиции и, следствено, перцепција на поголем авторитет.

Во следната контингентна табела (додаток 2) насловите се дистрибуирани според автор(ка) на поговор и жанр, со што повторно добиваме увид во стручноста или, пак, книжевните претпочитања на одредени филолози и книжевници. Во долунаведениот приказ (табела 6) можеме да ги видиме првите 15 полиња во кои авторите се рангирани според тоа колку поговори напишале, па, така, убедливо доминира Зоран Анчевски со 22 поговора, а на второ место се Драги Михајловски со 7 и Санде Стојчески со 6.

Табела 6. Англофони наслови според авйор (ка) на йогоовор и жанр. Збирните фреквенции се рангирани. Прикажани се првите 15 полиња

\begin{tabular}{|c|c|c|c|c|c|}
\hline \multirow[b]{2}{*}{ Автор(ка) на поговор } & \multicolumn{4}{|c|}{$\begin{array}{c}\text { Жанровска } \\
\text { класификација }\end{array}$} & \multirow{2}{*}{ 兑 } \\
\hline & $\begin{array}{l}\tilde{\tilde{\tilde{O}}} \\
\stackrel{8}{0} \\
\underline{E}\end{array}$ & $\begin{array}{l}\stackrel{\frac{\sigma}{3}}{\vec{N}} \\
\stackrel{0}{0} \\
0\end{array}$ & $\begin{array}{l}\sum_{\tilde{E}}^{\mathbb{J}} \\
\text { : }\end{array}$ & 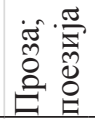 & \\
\hline Анчевски, Зоран & 13 & 7 & 2 & & 22 \\
\hline Михајловски, Драги & & 6 & 2 & & 8 \\
\hline Стојчески, Санде & 6 & 1 & & & 7 \\
\hline Додовски, Иван & 5 & & 1 & & 6 \\
\hline Витанова-Стрезова, Соња & 6 & & & & 6 \\
\hline Малеска, Калина & 5 & & 1 & & 6 \\
\hline Христовска, Виолета & 5 & & & & 5 \\
\hline Теофилова, Зорица & 4 & 1 & & & 5 \\
\hline Цветковски, Бранко & 5 & & & & 5 \\
\hline Кошка-Хот, Рајна & 2 & & 3 & & 5 \\
\hline Стојменска-Елзесер, Соња & 4 & & & & 4 \\
\hline Лафазановски, Ермис & 4 & & & & 4 \\
\hline Алаѓозовски, Роберт & 4 & & & & $\overline{4}$ \\
\hline Велев, Илија & 4 & & & & 4 \\
\hline Илиева, Александрина & 4 & & & & $\overline{4}$ \\
\hline
\end{tabular}




\section{5 Заклучок}

Прегледот и анализата на карактеристиките на англофоните наслови објавени

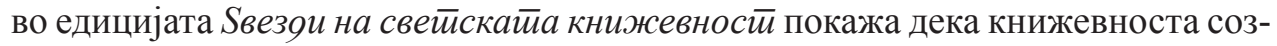
дадена на англиски јазик, каде што доминираат англиската и американската книжевност, зазема повеќе од една четвртина од канонот што уредниците на едицијата го сметаат за светска класика. Овие дела главно потекнуваат од 20 век, и покрај тоа што уредниците имале цел светскиот канон да вклучува автори родени пред 1910 година. Како и во другите светски канони, жанровски доминира прозата, а во рамките на прозата најдоминантен е романот, додека поезијата и драмата се застапени во значајно помал размер. Што се однесува до родовата распределба, во канонот на SCK доминираат машки автори, преведувачките се, главно, жени (иако најетаблираните како Драги Михајловски, Зоран Анчевски и Богомил Ѓ узел се мажи), додека кај авторите на поговорите преовладуваат мажите. Се јавуваат неколку издавачки куќи како издавачи на делата во едицијата, кои меѓусебно се комбинираат и затоа е невозможно да се процени уделот на секоја засебна издавачка куќа во производството на преведеното дело. Се гледа корелација во соработката на извесни преведувачи со извесни издавачки куќи. Истражувањето ги покажа и корелациите меѓу преведувачите и жанрот во кој најчесто преведуваат, како и авторите на поговори и жанрот за кој пишуваат.

Конечно, при обидот да се направи темелно истражување на владиниот

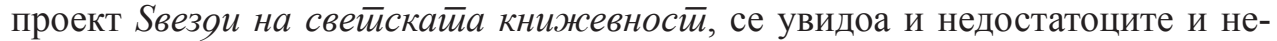
доследностите во неговото создавање. И покрај тоа што во едицијата се преземени и одново објавени преводи што веќе постојат и се објавени, како, на пример, преводите на Драги Михајловски и Богомил Ѓ узел, ова истражување не испита колку дела биле одново преведени во кусиот рок од четири години, зашто извесни дела биле препечатувани, а други не, а и не се осврна на квалитетот на објавените преводи. Сепак, со еден ваков темелен, но и првичен увид во англофоните наслови објавени во едицијата, ова истражување има надеж дека ќе предизвика една таква анализа. Понатаму, целокупен увид во обемот, практиката и карактеристиките на преведувањето од англиски на македонски јазик во рамките на оваа едиција може да произлезе откако ќе се земат предвид и делата преведени посредно од англиски јазик. А, за уште појасен увид во застапеноста на преведувачите, авторите на поговори и издавачките куќи вклучени во проектот, потребно е да се направи анализа на карактеристиките на сите наслови објавени во едицијата SCK. Конечно, се надевам дека ова истражување ќе поттикне анализа и на другите капитални книгоиздателски проекти на тогашната влада, кои во многу краток временски период продуцираа преводи на дополнителни стотици наслови - едициите Нобеловции и Свейско книжевно бог̄айсйво. 


\section{Библиографија}

Бужаровска, Р. (2015). Игри со ловците во 'ржта. Куличурен живой, (1/2): 50-54.

Гу урчинова, А и Стојменска-Елзесер, С. (1992). Светската книжевност во превод на македонски јазик (1945-1990). Сйекӣар, Х (19): 93-107.

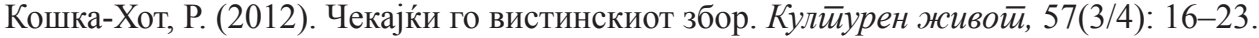

Маџунков, М. (2012). Звезди на светската книжевност: вовед кон едицијата. Наше йисмо, 18 (73/74): 2-5.

Никуљски, О. (2013). Јазикот, литератата и преводот - сложена интеракција. Кулйурен живот, (3/4): 6-11.

Танески, 3. (2013). Критиката на книжевните преводи: неопходни фактори и простор

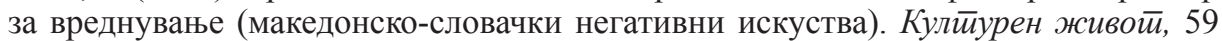
$(1 / 2): 38-47$.

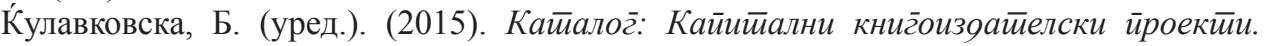
Скопје: Министерство за култура на Република Македонија

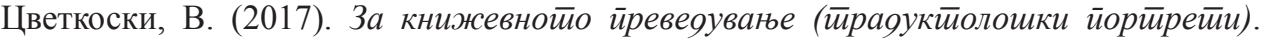
Скопје: Макавеј.

Андоновска, Д. (2020). За некои недоследности и стилската некохеренција во преводот на Даблинции. [Интернет] Окно. Достапно на https://okno.mk/node/84558. [Пристапено на 1.9.2020]

Димитрова, Б. (2020). Безбојниот јазик во Бојайа на йурӣурой. [Интернет] Окно. Достапно на https://okno.mk/node/84846. [Пристапено на 1.9.2020]

Ивановска, А. (2019). За јазикот на глувците, луѓето и преведувачот. [Интернет] Окно. Достапно на https://okno.mk/node/78916. [Пристапено на 1.9.2020]

Малеска, К. Зошто страв од колоквијалниот јазик? [Интернет] Окно. Достапно на https://okno.mk/node/42715 [Пристапено на 1.9.2020]

Рашко, А. (2019). Залудна потрага по љубов на блудниот син. [Интернет] Окно. Достапно на https://okno.mk/node/79160. [Пристапено на 1.9.2020]

Спасиќ, В. (2020). Најблескавата sвезда на светската книжевност. [Интернет] Окно. Достапно на https://okno.mk/node/84670. [Пристапено на 1.9.2020]

Станојевиќ, Н. (2019). За македонските преводи на Макбей. [Интернет] Окно. Достапно на https://okno.mk/node/79024. [Пристапено на 1.9.2020]

Државен завод за статистика: Број на дипломирани студенти во 2019 година. (26 мај 2020). Достапно на http://www.stat.gov.mk/PrikaziSoopstenie.aspx?id=28\&rbr=3317. [Пристапено на 1.9.2020]

Каталог на книги, Министерство за образование и наука. Достапно на http:// www.1000knigi.mon.gov.mk/katalog_za_sajt.pdf. [Пристапено на 1.9.2020]

Родот и економијата. Рооов реакӣор. [Интернет] Достапно на http://rodovreactor.mk/ subject/economy/. [Пристапено на 1.9.2020]

Index Translationum - World Bibliography of Translation. (2003). [Online] Available at http://portal.unesco.org/culture/en/ev.php-URL ID $=7810 \& U R L \quad D O=D O$ TOPIC\&URL SECTION=201.html [Accessed: September 1 ${ }^{\text {st }}, 2020$ ]

Three Percent: a resource for international literature at the University of Rochester. (2018). [Online] Available at http://www.rochester.edu/College/translation/threepercent/ translation-database/?fbclid=IwAR3o1sSY3biSYJxgRvntc3dpAWExmp9gndlqZF2y4 AU4XHVtViPGC7w8bh4 [Accessed: September 1 $1^{\text {st }}, 2020$ ] 


\section{Додатоци}

Додаток 1. Англофони наслови според ӣревеяувач(ка) и изяавачка куќа. Збирните фреквенции се рангирани. Преведувач(к)ите што се појавуваат и во наслови со повеќе преведувач(к)и се болдирани и до нив е наведен бројот на дополнителни наслови.

Преведувач(ка)

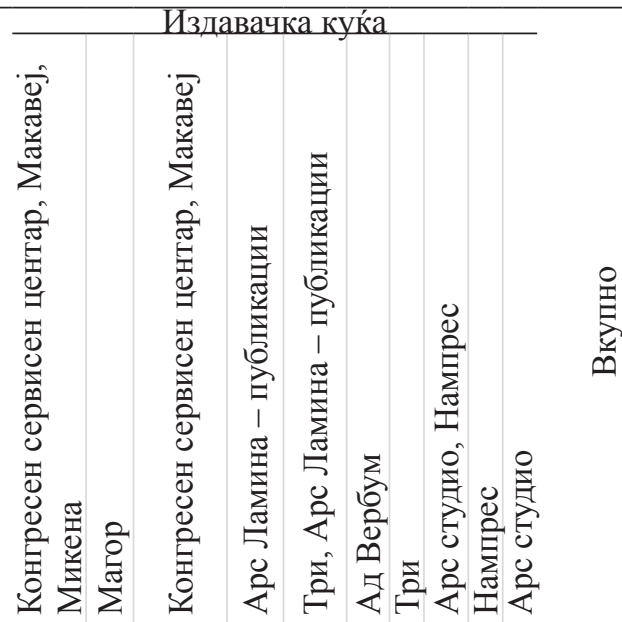

\begin{tabular}{|c|c|c|c|c|c|c|c|c|}
\hline Џонс, Марија (+4) & & 10 & & & & & & 10 \\
\hline Теофилова, Зорица & & 8 & & 1 & & 1 & & 10 \\
\hline Михајловски, Драги (+1) & & & 8 & & & & & 8 \\
\hline Анчевски, Зоран (+2) & 2 & 6 & & & & & & 8 \\
\hline Илковска, Ивана & & & & 4 & & & 2 & 1 \\
\hline Балоска, Ивана & 3 & & 3 & & & & & 6 \\
\hline Гароска-Ацеска, Катица (+2) & 4 & & & & & & & 5 \\
\hline Ѓ узел, Богомил (+2) & 2 & & & & 3 & & & 5 \\
\hline Тодорова, Марија & 4 & & & & & & & 4 \\
\hline Цветковски, Владимир & 2 & & 1 & & 1 & & & 4 \\
\hline Кошка-Хот, Рајна (+3) & 2 & 2 & & & & & & 4 \\
\hline Утковска, Јасмина & 1 & & & 3 & & & & 4 \\
\hline Пемова, Василка & 3 & & & & & & & 3 \\
\hline Мицкоски, Николче & 2 & & 1 & & & & & 3 \\
\hline Богеска-Анчевска, Благородна (+1) & 3 & & & & & & & 3 \\
\hline Малеска, Калина & 2 & & & & 1 & & & 3 \\
\hline Јанева, Калина (+1) & 2 & & 1 & & & & & 3 \\
\hline Чаповска, Вера & 3 & & & & & & & 3 \\
\hline Бакалинова-Атанасова, Зора & 2 & & & & & & & 2 \\
\hline БуразерКитановска, Мирјана & 1 & & & & 1 & & & 2 \\
\hline Костов, Миле (+1) & & & & & & 2 & & 2 \\
\hline Маџоска, Стефанија & & & & 2 & & & & 2 \\
\hline Христовска, Виолета & & 2 & & & & & & 2 \\
\hline Бужаровска, Румена (+1) & & 2 & & & & & & 2 \\
\hline Ковилоски, Филип & 2 & & & & & & & 2 \\
\hline
\end{tabular}




\begin{tabular}{|c|c|c|c|c|c|c|c|c|}
\hline Ковилоска, Офелија & & & 1 & 1 & & & & 2 \\
\hline Саревска-Тодоровска,Марија & & & & 1 & & 1 & & \\
\hline ГавровскаТаска & & 1 & & & & & & \\
\hline Чемерски, Огнен & 1 & & & & & & & \\
\hline Утковска, Николина & 1 & & & & & & & \\
\hline $\begin{array}{l}\text { Гузел, Богомил; Арсовска, Љуби- } \\
\text { ца;Кошка-Хот, Рајна;Јанева, Калина }\end{array}$ & & 1 & & & & & & \\
\hline Шонс, Марија; Банова, Бисера & & 1 & & & & & & \\
\hline Ғузел, Богомил;Џонс, Марија;Бах- & & 1 & & & & & & \\
\hline $\begin{array}{l}\text { тијароска, Елида } \\
\text { Тодоровски, Гане }(+1)\end{array}$ & & & & 1 & & & & \\
\hline $\begin{array}{l}\text { Кошка-Хот, Рајна; Гароска-Ащеска, } \\
\text { Катища }\end{array}$ & 1 & & & & & & & \\
\hline Главинова-Јовановска, Софија & 1 & & & & & & & \\
\hline Костоска,Викторија & 1 & & & & & & & \\
\hline Арсовска, Љубица;Кошка-Хот, Рајна & & 1 & & & & & & \\
\hline Бабамова, Екатерина & & & & & 1 & & & \\
\hline Цветкоски, Владимир & 1 & & & & & & & \\
\hline $\begin{array}{l}\text { Гароска-Ацеска, Катица; Стојкова, } \\
\text { Маја }\end{array}$ & & 1 & & & & & & \\
\hline Тодорова-Јанешлиева, Љубица & & 1 & & & & & & \\
\hline Ничота, Јана;Петровска, Весна & & & & & 1 & & & \\
\hline Гиревска, Марија (+2) & 1 & & & & & & & \\
\hline Гилевски, Аполон & & & & 1 & & & & \\
\hline $\begin{array}{l}\text { Гиревска, Марија;Илиевска-Марјано- } \\
\text { виќ, Јасмина }\end{array}$ & & 1 & & & & & & \\
\hline Ристевски, Владимир & & & 1 & & & & & \\
\hline Костов, Миле;Тодоровски, Гане & & & & & & 1 & & \\
\hline Серафимов, Свето & & 1 & & & & & & \\
\hline $\begin{array}{l}\text { Џепароски, Иван;Михајловски, Дра- } \\
\text { ги;Пејчинова, Ана }\end{array}$ & & 1 & & & & & & \\
\hline Спирковска, Марија; Илиева, Гу ургица & & & & 1 & & & & \\
\hline Џонс, Марија; Талевска, Викторија & & 1 & & & & & & \\
\hline Сталев, Георги; Неновска, Маргарита & & & & & & & 1 & \\
\hline Ширилова, Велика & & 1 & & & & & & \\
\hline Тасев, Саше & & 1 & & & & & & \\
\hline $\begin{array}{l}\text { Богеска-Анчевска, Благородна; Џонс, } \\
\text { Марија }\end{array}$ & & 1 & & & & & & \\
\hline Арсовска, Љубица (+2) & 1 & & & & & & & \\
\hline Јанковски, Владимир & 1 & & & & & & & \\
\hline $\begin{array}{l}\text { Лазаров, Ристо;Анчевски, Зоран;Бах- } \\
\text { тијароска. Елида }(+1)\end{array}$ & & 1 & & & & & & \\
\hline Милошевска, Ленче & 1 & & & & & & & \\
\hline $\begin{array}{l}\text { Анчевски, Зоран;Гиревска, Марија;- } \\
\text { Бужаровска. Румена }\end{array}$ & & 1 & & & & & & \\
\hline МечкароскаСимјаноска, Наташа & & & 1 & & & & & \\
\hline Вкупно & 504 & 46 & 17 & 15 & 8 & 4222 & 11 & 1 \\
\hline
\end{tabular}


Додаток 2. Англофони наслови според авйор (ка) на йог̄oвор и жанр. Збирните фреквенции се рангирани. Автор(к)ите што се појавуваат и во наслови со повеќе автор(к)и на поговор се болдирани и до нив е наведен бројот на дополнителни наслови.

\begin{tabular}{|c|c|c|c|c|c|}
\hline \multirow[b]{2}{*}{ Автор(ка) на поговор } & \multicolumn{4}{|c|}{$\begin{array}{c}\text { Жанровска } \\
\text { класификација }\end{array}$} & \multirow[b]{2}{*}{ 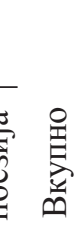 } \\
\hline & 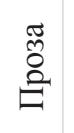 & 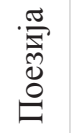 & 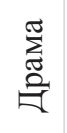 & 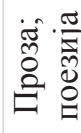 & \\
\hline Анчевски, Зоран & 13 & 7 & 2 & & 22 \\
\hline Михајловски, Драги & & 6 & 2 & & \\
\hline Стојчески, Санде & 6 & 1 & & & \\
\hline Додовски, Иван & 5 & & 1 & & \\
\hline Витанова-Стрезова, Соња & 6 & & & & \\
\hline Малеска, Калина & 5 & & 1 & & \\
\hline Христовска, Виолета & 5 & & & & \\
\hline Теофилова, Зорица & 4 & 1 & & & \\
\hline Цветковски, Бранко & 5 & & & & \\
\hline Кошка-Хот, Рајна & 2 & & 3 & & \\
\hline Стојменска-Елзесер, Соња & 4 & & & & \\
\hline Лафазановски, Ермис & 4 & & & & 4 \\
\hline Алаѓозовски, Роберт & 4 & & & & 4 \\
\hline Велев, Илија & 4 & & & & \\
\hline Илиева, Александрина & 4 & & & & \\
\hline Апостолоска, Маја & 3 & & & & \\
\hline Костов, Миле & 1 & 1 & & 1 & 3 \\
\hline Цветковски, Владимир & 3 & & & & \\
\hline Србиновска, Славица & 1 & & 2 & & \\
\hline Лужина, Јелена & 1 & & 2 & & \\
\hline Џепароски, Иван & 2 & 1 & & & 3 \\
\hline Цветкоски, Бранко & 2 & & & & \\
\hline Тасевски, ЈовицаЕтернијан & 2 & & & & \\
\hline Бужаровска, Румена & 2 & & & & \\
\hline Гузел, Богомил & & 2 & & & \\
\hline Корвезироска, Оливера & 2 & & & & \\
\hline Аврамовска, Наташа & 2 & & & & \\
\hline нема & 2 & & & & \\
\hline Тасевскски, Јовица & 1 & & & & \\
\hline $\begin{array}{l}\text { Капушевска-Дракулевска, } \\
\text { Лидија }\end{array}$ & 1 & & & & \\
\hline Ковилоска, Офелија & & & 1 & & \\
\hline Давидовска, Лидија & 1 & & & & \\
\hline Бојаџиевска, Маја & 1 & & & & \\
\hline Тодоровски, Гане & & 1 & & & \\
\hline Ќулафкова, Катица & 1 & & & & \\
\hline Ташковски, Братислав & 1 & & & & \\
\hline
\end{tabular}




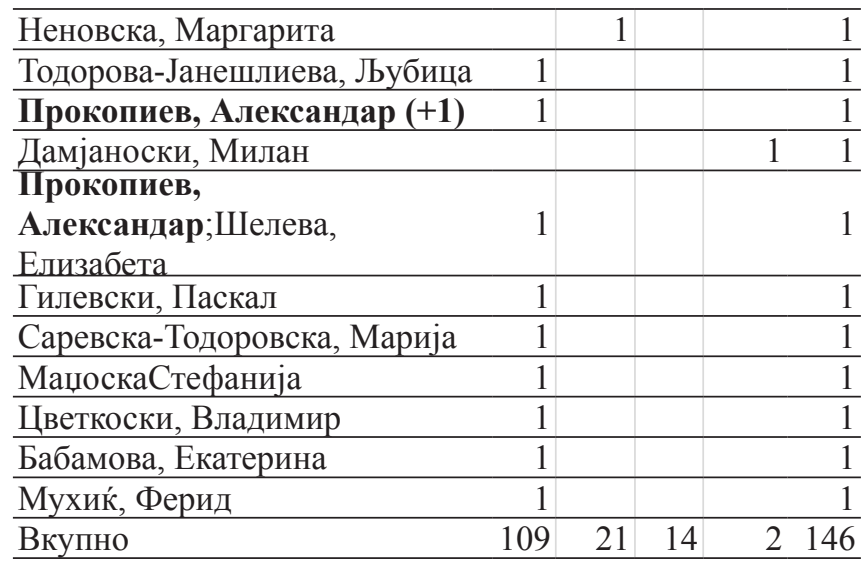

